\title{
Developing and evaluating a methodology for business process improvement
}

\section{Sola Adesola and Tim Baines}

\section{Introduction}

Business environments are complex. Almost everywhere organisations are undergoing rapid and significant changes driven by such pressures as customer expectations, new technologies, and growing global competition. As a result, many business processes within organisations are dynamic and constantly changing. In order to survive in such environments, practitioners are forced to continually revise their business processes to respond quickly to changes. There are some methodologies and tools available to help businesses improve their processes, however, none of these adequately support the practitioner through all stages in the business process improvement (BPI) activity. On this basis, this paper addresses the limitation by presenting a research that has formed and tested a generic and practical workbook-based methodology, termed model-based and integrated process improvement (MIPI) methodology for implementing process-based change and improvement.

The BPI workbook methodology has been developed on the basis of existing literature and initially refined through discussion with experts in the field. The tool was then tested in two stages; first a primary application by the researcher in the public sector by means of case study. After refinement, the methodology was more widely tested through case studies, without researcher intervention, at three service sector companies. Through this process the methodology has been shown to be feasible, usable and useful.

This paper is structured to firstly present the need for an effective methodology and evaluation. A background of literature in BPI is first developed, followed by detailed research aim and programme. A description of the method used to develop and evaluate the methodology is presented. This is followed by an overview of the complete BPI methodology. The final section concludes this paper and identifies areas for future research.

\section{Background}

This section sets the context to this work by highlighting the need for a structured methodology for BPI, and also that such methodology must be validated and refined through a systematic and rigorous evaluation.

\section{Business process improvement as a concept}

The focus of this paper is on the field of business process improvement (BPI). In this research, the concept has been used to refer to any process-based change. Although it is a popular concept, there are many terminologies that are loosely associated with the concept, for example business process improvement, originally coined in 1991 by James Harrington (Harrington, 1991), and business process re-engineering (BPR) put forward by Michael Hammer in 1990 (Hammer, 1990). To understand the differences in these approaches, it is useful to explore some fundamental terminologies.

The term "process" is an important concept and has received much attention and many interpretations from different perspectives (Childe et al., 1994; Harrison, 1995). A popular definition is:

The transformation of inputs into outputs; the inputs can be resources or requirements, whilst the outputs can be products or results. The outputs may or may not add value and could be an input to another process (Harrington, 1991).

When this concept is applied to a commercial organisation, the term "business process" is used. A number of specific definitions have become widely adopted in the literature on the design and management of business processes.

Here Tinnila (1995), summarises a business process as: 
A group of logically related tasks that use the resources of the organisation to provide defined results in support of the organisation's objectives.

Business process improvement (BPI) and business process re-engineering (BPR), introduced above, suffer from having less universally accepted definitions. BPI is often thought of as:

A methodology that is designed to bring about step-function improvements in administrative and support processes using approaches such as process benchmarking, process redesign and process re-engineering (Harrington et al., 1997).

Conversely, BPR is usually associated with a much more radical change to a business process (Hammer and Champy, 1993). The focus of the work described in this paper has been BPI.

\section{BPI and the associated research issues}

The most frequently asked question among practitioners faced with a BPI project seems to be "how to do it?" "what do we do next?" and "what methodology do you follow?" (Vakola and Rezgui, 2000). On this basis, a key research issue associated with BPI has been the methodology through which the technique can be applied. Whilst there are methodologies in the public domain, (e.g. Kettinger et al., 1997; Harrington, 1991; Smart et al., 1998; Klein, 1994), it appears that a number of short comings exist and that there is a lack of an effective methodology for the BPI implementation. One concern for example, is that current methodologies provide limited guidance to practitioners involved in the activity of BPI. The lack of a structured step-by-step approach and associated guidelines has been noted by many researchers (Harrington, 1991; Kaplan and Murdoch, 1991; Childe et al., 1994). This has led to the call for an effective, systematic and planned methodology to guide the successful implementation process (Davenport, 1993; Robb, 1995; Vakola and Rezgui, 2000). For example, in a sample of consultants, Archer and Bowker (1995) confirmed that structured methodology was seen as critical, important and useful. Likewise, studies by Grover et al. (1995) and Grover (1999) revealed that an appropriate methodology was critical for achieving success.

A second key research issue is concerned with knowing that a BPI methodology does indeed work. Many methodologies have been developed and applied without a systematic and rigorous assessment to determine whether the tools and methods are of use to practitioners. The evaluation of BPI methodology application is critical and yet understudied. Childe et al. (1994) remarked that existing approaches lack critical evaluation in practice. Vakola and Rezgui (2000) observed that the application of many existing methodologies is not feasible due to associated application cost, time required or lack of knowledge about likely benefits. The research presented in this paper takes the view that, if the methodologies are to be used by practitioners, a rigorous testing of application is needed. This would ensure that the methods are not just usable by practitioners, but can lead to real improvement.

A third key research area worth mentioning concerns the task of evaluation as a step within a methodology. This differs to the evaluation issue mentioned above, as it is focused at the proposed business process rather than the effectiveness of the overall methodology itself.

In summary, it is apparent that research is needed to develop a structured and practical methodology for BPI, and that this should be subject to rigorous evaluation in real case projects to ensure it is effective when used by the practitioners.

\section{Research aim and programme}

As identified in the previous section, there is an important need to expand the capability of existing BPI methodologies to include structured and procedural aspects. The work described in this paper has been a first step in this process. Here, the aim has been to develop a practical methodology to support the implementation of business process improvement and to validate its effectiveness in organisations. Therefore, there are three objectives that have been chosen to address this, namely to:

1. Develop a structured and procedural method of business process improvement. 
2. Seek expert opinions to identify and contrast this method against leading industry practice.

3. Evaluate and refine the method through practical application.

Each objective has been addressed in turn by a specific phase of research and these are described as follows.

\section{Phase 1: forming the initial structure and content of the BPI methodology}

The purpose of this initial stage was to develop a prototype methodology based around current frameworks where possible. From the review and analysis of $17 \mathrm{BPIs}$ against key performance indicators, four frameworks were selected that met the criteria of structured, generic, simple, flexible, model-based and industry relevant (Kettinger et al., 1997; Harrington, 1991; Smart et al., 1998; Klein, 1994). Through contrasting these frameworks, five common phases become apparent, namely: initiation, diagnosis, design, implementation and process management. This is illustrated in Figure 1.

The top column of the mapping table displays the number of stages covered by the selected generic methodologies in the left row. The phases are then mapped with the generic methodologies to form a new structure. Across the bottom of the table, the shading key for the selected methodology stages signifies the five common phases as illustrated. The mapping of frameworks against phases has not been entirely straight forward as noted by the shading key shown in Figure 1. Stage 4 for example shaded white and marked as (D), illustrates that in the case of Harrington (1991) measurement straddles between the diagnosis and design phase.

The content for the methodology was developed on the basis that the common phases identified, shown across the bottom of the table, are the actual stages of the methodologies that were identified through this analysis. Each stage has then been described in terms of objective, target, conceptual basis, scope, structure, tools and techniques, participants, outputs and delivery mechanism (Avison and Fitzgerald, 1988). The output of this conceptual development was a seven-step prototype BPI methodology as described in Adesola and Baines (2000). As shown in Figure 1, these steps are:

1. assess readiness;

2. outline process under review;

3. detailed data collection;

4. form model of current process;

5. assess and redesign process;

6. implement process; and

7. review process.

\section{Phase 2: initial confirmation of the BPI methodology}

To develop the methodology further, an initial validation process was conducted to seek expert opinions to contrast the methodology against leading industry practice. "Experts" were chosen from people who were academics, consultants or practitioners in the field of business BPI. Then, using a semi-structured interview approach, 16 experts were questioned. These were from different locations and industry sectors. Of these groups, there were three manufacturing companies, one financial service, four consultancy companies, and eight academics. Questionnaires were used to guide and focus the interview on key areas. The questions were set to first confirm and validate the structure of the BPI methodology. Second, to investigate further the analytical activities necessary in each stage of the methodology.

The main findings from the 16 interviews were as follows. First, the methodology structure appeared valid. Most of the comments made were additions rather than flaws. Advice was given and adopted on iterations, risk assessments, checklists, and the form of any resultant. This phase resulted in the formation of the BPI methodology that was then ready for industrial assessment. 


\section{Phase 3: testing the BPI methodology through industrial application}

The BPI methodology was then evaluated to determine whether it was valuable in practice. The approach here was first to guide the application of the methodology in practice, and to assess whether the methodology could provide practical aid in the activity of BPI. Therefore, the researcher set out to determine the following:

1. Could the methodology be used in practice?

2. Are there any problems and difficulties with the methodology?

3. Are the results worth the effort and are they useful to the host organisation?

\section{Design of the testing procedure}

Testing was conducted in two steps. First, a single case study was carried out in which the researcher participated to nurse the newly formed BPI methodology through the assessment. Here, the focus was mainly on research question one above. Having successfully completed this first trial, a second set of more searching case studies was carried out. In these cases, the researcher did not participate, but instead observed the participating companies apply the methodology themselves.

To assess whether the methodology was working, a procedural approach of evaluating process research was adopted Platts (1990). As Platts described, this approach is:

An organised and systematic procedure which involves people in a participative manner, both in basic data collection and joint discovery through its subsequent analysis, leading to creatively identifying improvement opportunities.

The subsequent assessment procedure consisted of three categories of measurement and were:

1. Feasibility: can the BPI methodology be followed?

2. Usability: is the BPI methodology workable? Are the steps, tools and techniques easy to use and apply?

3. Usefulness: is the BPI methodology worth following? Does the methodology produce results that the business finds helpful?

Using these, 15 sets of associated indicators were established, such as "were all the steps in the methodology completed?" These formed the evaluation procedure for the methodology.

\section{The case companies}

In total, the BPI methodology was assessed at four companies. In case 1 (public sector) the researcher was the main user and facilitated the methodology. In case 2 (IT service provider), case 3 (logistics), and case 4 (public sector), the methodology was directly applied by an experienced in-house facilitator, with the researcher acting as observer of the process.

\section{Evaluation result}

Based on the evaluation described above of feasibility, usability and usefulness, the following conclusions were drawn against each of these criteria:

- Feasibility: can the BPI methodology be applied and followed? The overwhelming outcome from this study was that the methodology can be followed through all stages of analysis.

- Usability: was the methodology easy to apply and use? Again, the conclusive finding throughout was that the methodology was easy to use and apply. Key reasons for this indicated the interactive meeting and workshop format throughout; the workbook guide, tools and techniques; and the group information capture and learning.

- Usefulness: did the methodology produce a useful result? The methodology was considered useful across the four case studies. The level of detail recorded in the post completion assessment was consistently high across the four cases. Through the use of the methodology, all four case study companies identified and improved their business processes. 
On completion of the assessment, the feedback of the participants and facilitators supported the credibility of the methodology. It can therefore be concluded that the testing and evaluation has demonstrated that the methodology has successfully captured business process improvement activity, and is now described in greater detail.

\section{The complete BPI methodology}

The methodology presented in this section is the final outcome of an iterative process from theory, practice, and case studies as described above. The BPI methodology has been given the acronym model-based and integrated process improvement (MIPI) methodology. It is a generic seven-step procedural approach that guides the actions and decisions of a process design team (see Figure 2). MIPI methodology can be used for both process improvement and reengineering initiatives. It addresses the "what" to do and "how" to make it happen with a participative team effort. It is a guide, not a procedure or manual. The structure for the final methodology shown in Figure 3 contains a hierarchical structure. Each step of the methodology includes: aim, actions, people involved, outcome/exit, checklists, hints and tips, and relevant tools and techniques.

An outline of the content of MIPI methodology in Table I shows the steps, key activities and tools, and techniques. Future paper will publish the workbook MIPI methodology.

Although MIPI methodology has been based on other frameworks for BPI/BPR, such as Kettinger et al. (1997); Davenport and Short (1990); Childe et al. (1994); Harrington (1991), it differs in the detail. For example, the methodology produced by Smart et al. (1998) is workbook-based but there is a clear difference in scope, as their methodology is targeted only at small-medium enterprises and does not formally consider post-BPR initiatives.

\section{Conclusions and future work}

This paper aims to contribute to both theory and practice. The BPI methodology developed here addresses the gap identified in the literature by capturing relevant elements and success factors to be considered in developing and evaluating an effective methodology for a BPI activity. The main outcome of this research is the creation of a practical and procedural methodology, to guide the practitioners through a series of well-defined structured steps necessary to make informed, consistent and efficient changes to business processes. It is a holistic workbook-based methodology with relevant tools and techniques, enabling the user to start the process-based change effectively at any point. The research has also contributed to the new knowledge on how to systematically assess a BPI methodology in practice. The process approach adopted provides a systematic, organised and participative procedure.

MIPI methodology has been applied, tested and evaluated. The methodology met the assessment criteria of feasibility, usability and usefulness. It has been shown that benefits can be gained from using the methodology and that the main objectives of the research have been successfully achieved.

This research has also exposed a series of issues for future work. First, the MIPI methodology needs to be further tested with more case studies to monitor its validity and generalisation. Second, investigation into the duration to complete the cycle needs to be carried out. Third, a framework for process maturity needs to be created to embed process users' skills into the methodology to reflect skill and knowledge competence. This would ensure that appropriate level of BPI methodology is tailored to match users' skill set. Finally, the whole MIPI methodology would benefit from being developed into an interactive web-based or CD-ROM application. This would offer better communication and self-learning, and also serve as a knowledge repository for the project team. 


\begin{tabular}{|c|c|c|c|c|c|c|c|c|c|}
\hline & \multicolumn{9}{|c|}{ Methodology Stages } \\
\hline Authors & 1 & \multicolumn{2}{|l|}{2} & \multicolumn{2}{|r|}{3} & 4 & 5 & 6 & 7 \\
\hline $\begin{array}{l}\text { Kettinger et al; } \\
\text { (1997) }\end{array}$ & $\begin{array}{l}\text { Envision } \\
\text { (A) }\end{array}$ & \multicolumn{2}{|l|}{$\begin{array}{l}\text { Initiate } \\
\text { (A) }\end{array}$} & \multicolumn{2}{|c|}{$\begin{array}{l}\text { Diagnose } \\
\text { (B) }\end{array}$} & $\begin{array}{l}\text { Redesign } \\
\text { (C) }\end{array}$ & $\begin{array}{l}\text { Reconstruct } \\
\text { (E) }\end{array}$ & $\begin{array}{l}\text { Evaluate } \\
\text { (F) }\end{array}$ & \\
\hline $\begin{array}{l}\text { Harrington, } \\
\text { (1991) }\end{array}$ & $\begin{array}{l}\text { Organise for } \\
\text { Improvement } \\
\text { (A) }\end{array}$ & \multicolumn{2}{|c|}{$\begin{array}{l}\text { Understand } \\
\text { Process } \\
\text { Characteristics } \\
\text { (B) }\end{array}$} & \multicolumn{2}{|c|}{$\begin{array}{l}\text { Streamline Process } \\
\text { (C) }\end{array}$} & $\begin{array}{l}\text { Measurement, } \\
\text { Control \& } \\
\text { Feedback } \\
\text { (D) }\end{array}$ & $\begin{array}{l}\text { Continuous } \\
\text { Improvement } \\
\text { (F) }\end{array}$ & & \\
\hline $\begin{array}{l}\text { Smart et al; } \\
\text { (1998) }\end{array}$ & $\begin{array}{l}\text { Develop } \\
\text { Strategy for } \\
\text { Change } \\
\text { (A) }\end{array}$ & \multicolumn{2}{|c|}{$\begin{array}{l}\text { Identify } \\
\text { Process } \\
\text { (B) }\end{array}$} & \multicolumn{2}{|c|}{$\begin{array}{l}\text { Analyse Process } \\
\text { (B) }\end{array}$} & $\begin{array}{l}\text { Redesign } \\
\text { (C) }\end{array}$ & $\begin{array}{l}\text { Implement } \\
\text { (E) }\end{array}$ & & \\
\hline Klein, (1994) & $\begin{array}{l}\text { Preparation } \\
\text { (A) }\end{array}$ & \multicolumn{2}{|c|}{$\begin{array}{l}\text { Identification } \\
\text { (B) }\end{array}$} & \multicolumn{2}{|l|}{$\begin{array}{l}\text { Vision } \\
\text { (A) }\end{array}$} & $\begin{array}{l}\text { Solution } \\
\text { (C) }\end{array}$ & $\begin{array}{l}\text { Transformation } \\
\text { (E) }\end{array}$ & & \\
\hline \multirow{2}{*}{$\begin{array}{l}\text { Common } \\
\text { Phases of the } \\
\text { BPI } \\
\text { Methodologies }\end{array}$} & Initiation & \multicolumn{4}{|c|}{ Diagnosis } & Design & Implementation & \multicolumn{2}{|c|}{$\begin{array}{c}\text { Process } \\
\text { Management }\end{array}$} \\
\hline & \multirow{2}{*}{$\begin{array}{l}\text { Assess } \\
\text { Readiness }\end{array}$} & \multirow{2}{*}{$\begin{array}{l}\text { Outline } \\
\text { Process } \\
\text { under } \\
\text { Review }\end{array}$} & \multirow{2}{*}{\multicolumn{2}{|c|}{$\begin{array}{l}\text { Detailed } \\
\text { Data } \\
\text { Collection }\end{array}$}} & \multirow{2}{*}{$\begin{array}{l}\text { Form } \\
\text { Model of } \\
\text { Current } \\
\text { Process }\end{array}$} & Assess \& & Implement & \multirow{2}{*}{\multicolumn{2}{|c|}{ Review process }} \\
\hline $\begin{array}{l}\text { Initial } \\
\text { Proposed } \\
\text { Methodology } \\
\text { Structure }\end{array}$ & & & & & & $\begin{array}{l}\text { Redesign } \\
\text { Process }\end{array}$ & $\begin{array}{l}\text { improved } \\
\text { Process }\end{array}$ & & \\
\hline
\end{tabular}

Key for Shading: A = Initiation; B = Diagnosis; C = Design; D = Diagnosis \& Design; E = Implementation; F = Process Management

Figure 1 Mapping selected BPI methodologies against the initial MIPI methodology structure

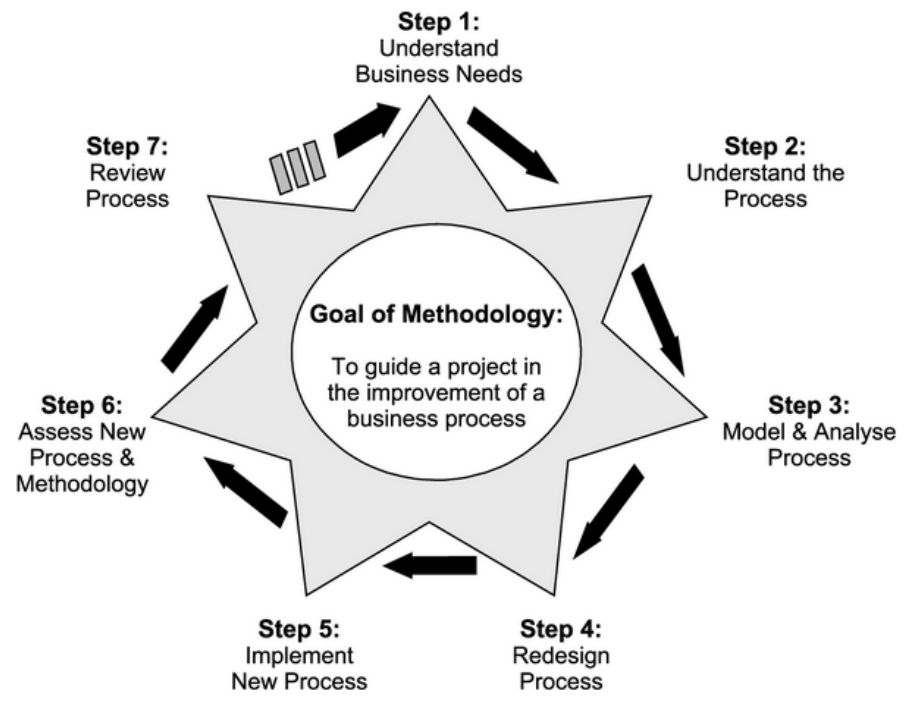

Figure 2A generic model for business process improvement

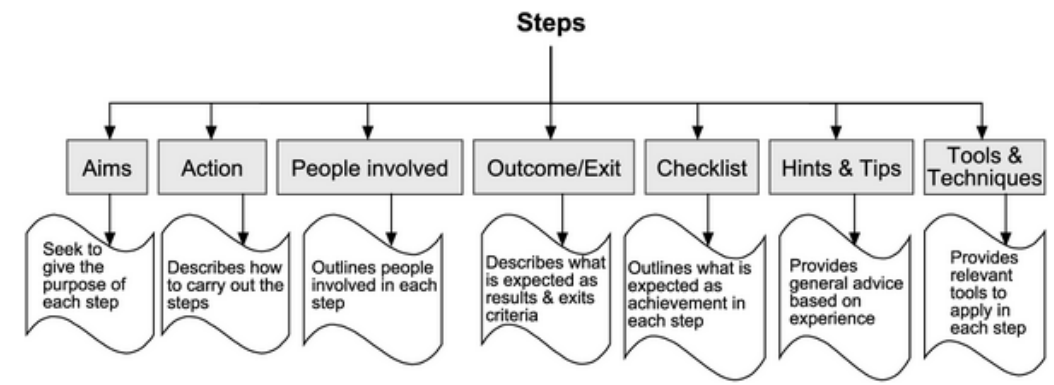

Figure 3 Hierarchical structure of MIPI methodology steps 


\begin{tabular}{|c|c|c|c|}
\hline & Step & Step description & Techniques \\
\hline 1 & $\begin{array}{l}\text { Understand } \\
\text { business needs }\end{array}$ & $\begin{array}{l}\text { Develop vision and strategic } \\
\text { objectives } \\
\text { Perform competitor analysis } \\
\text { Develop organisational model } \\
\text { Evaluate current practices, } \\
\text { prioritise objectives } \\
\text { Scope change } \\
\text { Establish measurable targets } \\
\text { Develop process objectives and } \\
\text { assess readiness } \\
\text { Obtain approval and initial } \\
\text { project resource } \\
\text { Benchmark the process }\end{array}$ & $\begin{array}{l}\text { Organisation model } \\
\text { SWOT analysis } \\
\text { Force field analysis } \\
\text { Readiness assessment } \\
\text { Stakeholder analysis } \\
\text { Process prioritisation matrix } \\
\text { Pareto analysis } \\
\text { Process performance table }\end{array}$ \\
\hline 2 & $\begin{array}{l}\text { Understand the } \\
\text { process }\end{array}$ & $\begin{array}{l}\text { Identify the business process } \\
\text { architecture } \\
\text { Scope and define the process } \\
\text { Capture and model the AS IS } \\
\text { process information } \\
\text { Model the process }\end{array}$ & $\begin{array}{l}\text { XPat process } \\
\text { IDEF0 } \\
\text { Walkthrough } \\
\text { Process flowchart } \\
\text { ABC } \\
\text { Cause and effect analysis }\end{array}$ \\
\hline 3 & $\begin{array}{l}\text { Model and analyse } \\
\text { process }\end{array}$ & $\begin{array}{l}\text { Verify and validate the model } \\
\text { Measure the existing process } \\
\text { performance } \\
\text { Analyse the business process }\end{array}$ & Value added analysis \\
\hline 4 & Redesign process & $\begin{array}{l}\text { Benchmark the process } \\
\text { Identify performance criteria for } \\
\text { re-design process } \\
\text { Identify focus of re-design } \\
\text { activity } \\
\text { Model and validate new TO BE } \\
\text { process model } \\
\text { Identify IT requirements } \\
\text { Estimate performance of } \\
\text { re-designed process }\end{array}$ & $\begin{array}{l}\text { Benchmarking } \\
\text { Creative silence workshop } \\
\text { Brainstorming }\end{array}$ \\
\hline 5 & $\begin{array}{l}\text { Implement new } \\
\text { process }\end{array}$ & $\begin{array}{l}\text { Plan the implementation } \\
\text { Obtain implementation approval } \\
\text { Review change management plan } \\
\text { Communicate the change } \\
\text { Technological development } \\
\text { Make new process operational } \\
\text { Train staff } \\
\text { Roll-out changes }\end{array}$ & \\
\hline 6 & $\begin{array}{l}\text { Assess new } \\
\text { process and } \\
\text { methodology }\end{array}$ & $\begin{array}{l}\text { Conduct process deployment and } \\
\text { performance data reflections } \\
\text { Revise organisational approach }\end{array}$ & $\begin{array}{l}\text { Action plan } \\
\text { Evaluation measurement report } \\
\text { Customers measurement survey }\end{array}$ \\
\hline 7 & $\begin{array}{l}\text { Review new } \\
\text { process }\end{array}$ & $\begin{array}{l}\text { Develop strategic view of the } \\
\text { business } \\
\text { Set process targets and } \\
\text { performance } \\
\text { Develop a plan to meet targets } \\
\text { Implement plan }\end{array}$ & Process improvement matrix \\
\hline
\end{tabular}

Table IBPI step activities and techniques

\section{References}

Adesola, S., Baines, T. (2000), "Developing a methodology for business process improvement", Proceedings of the 4th International Conference on Managing Innovative Manufacturing, Aston Business School, Birmingham, pp.28-35.

Archer, R., Bowker, P. (1995), "BPR consulting: an evaluation of the methods employed", Business Process Reengineering \& Management Journal, Vol. 1 No.2, pp.28-46.

Avison, D.E., Fitzgerald, G. (1988), Information Systems Development, Blackwell Scientific Publications, Oxford, .

Childe, S.J., Maull, R.S., Bennett, J. (1994), "Frameworks for understanding business process reengineering", International Journal of Operations \& Production Management, Vol. 14 No.12, pp.22-34.

Davenport, T.H. (1993), Process Innovation: Reengineering Work through Information Technology, Harvard Business School Press, Boston, MA, .

Davenport, T.H., Short, J. (1990), "The new industrial engineering: information technology and business process redesign", Sloan Management Review, Vol. 31 No.4, pp.11-27.

Grover, V. (1999), "From business reengineering to business process change management: a longitudinal study of trends and practices", IEEE Transactions on Engineering Management, Vol. 46 No.1, pp.36-46. 
Grover, V., Jeong, S.R., Kettinger, W.J., Teng, J.T.C. (1995), "The implementation of business process reengineering", Journal of Management Information Systems, Vol. 12 No.1, pp.109-44.

Hammer, M. (1990), "Reengineering work: don't automate, obliterate", Harvard Business Review, Vol. 68 No.4, pp.104-12.

Hammer, M., Champy, J. (1993), Reengineering the Corporation: A Manifesto for Business Revolution, 1st ed., HarperBusiness, New York, NY, .

Harrington, H.J. (1991), Business Process Improvement: The Breakthrough Strategy for Total Quality, Productivity and Competitiveness, McGraw-Hill, New York, NY, .

Harrington, H.J., Esseling, E.C., Van Nimwegen, H. (1997), Business Process Improvement - Documentation, Analysis, Design and Management of Business Process Improvement, McGraw-Hill, New York, NY, .

Harrison, A. (1995), "Business processes: their nature and properties", in Burke, G., Peppard, J. (Eds), Examining Business Process Reengineering - Current Perspectives and Research Directions, Kogan Page, London, pp.60-9.

Kaplan, R.B., Murdoch, L. (1991), "Rethinking the corporation: core process redesign", The McKinsey Quarterly, Summer, Vol. 2 pp.27-43.

Kettinger, W., Teng, J., Guha, S. (1997), "Business process change: a study of methodologies, techniques, and tools", MIS Quarterly, March, Vol. 21 pp.55-80.

Klein, M.M. (1994), "Reengineering methodologies and tools", Information Systems Management, Vol. 11 No.2, pp.30-5.

Platts, K.W. (1990), "Manufacturing audit in the process of strategy formulation", PhD thesis, University of Cambridge, Cambridge.

Robb, D.J. (1995), "Business process innovation: reengineering for operations renewal", Operations Management Review, Vol. 10 No.3, pp.12-15.

Smart, P.A., Childe, S.J., Maull, R.S. (1998), "Supporting business process reengineering in industry: towards a methodology", in Gulladge, R., Elzinga, J. (Eds),Process Engineering: Advancing the State-of-the-Art, Kluwer Academic, Boston, MA, pp.283-317.

Tinnila, M. (1995), "Strategic perspectives to business process redesign", Business Process Reengineering \& Management Journal, Vol. 1 No.1, pp.44-50.

Vakola, M., Rezgui, Y. (2000), "Critique of existing business process re-engineering methodologies - the development and implementation of a new methodology", Business Process Management Journal, Vol. 6 No.3, pp.238-50. 